\title{
Antimicrobial activity of root canal filling materials
}

\author{
Liubchenko Olga ${ }^{1}$, Velihoria Iryna ${ }^{2}$, Poliakova Svetlana ${ }^{3}$, Pushkar Liudmila ${ }^{4}$, Nikonova Anna ${ }^{5}$, Vashakidze Nazi $^{6}$, Jikia Maia $^{7 *}$ \\ ${ }^{1}$ Professor, Department of dentistry and therapeutic dentistry, Kharkiv Medical Academy of Postgraduate Education, Kharkov, Ukraine. \\ ${ }^{2}$ Associate Professor. Department of dentistry and therapeutic dentistry, Kharkiv Medical Academy of Postgraduate Education, Kharkov, Ukraine. \\ ${ }^{3}$ Associate Professor, Department of dentistry and therapeutic dentistry, Kharkiv Medical Academy of Postgraduate Education, Kharkov, Ukraine. \\ ${ }^{4}$ Associate Professor. Department of dentistry and therapeutic dentistry, Kharkiv Medical Academy of Postgraduate Education, Kharkov, Ukraine. \\ ${ }^{5}$ Clinical Ordinator, Department of dentistry and therapeutic dentistry, Kharkiv Medical Academy of Postgraduate Education, Kharkov, Ukraine. \\ ${ }^{6} \mathrm{Ph} . \mathrm{D}$. Student.
}

${ }^{7}$ Professor, Head of Scientific Research Division, Dentistry Department, School of Health Sciences.

*Corresponding Author: Jikia Maia, Professor, Head of Scientific Research Division, Dentistry Department, School of Health Sciences.

Received date: February 08, 2021; Accepted date: April 06, 2021; Published date: April 12, 2021

Citation: P Svetlana, P Liudmila, N Anna, V Nazi, J Maia. (2021) Antimicrobial activity of root canal filling materials. International Journal of Clinical Case Reports and Reviews. 7(1); DOI:10.31579/2690-4861/116

Copyright: (C) 2021 Jikia Maia, This is an open-access article distributed under the terms of the Creative Commons Attribution License, which permits unrestricted use, distribution, and reproduction in any medium, provided the original author and source are credited.

\begin{abstract}
The antimicrobial activity of filling materials was studied to improve the quality of treatment of complicated caries in vitro. Resorcin-formalin cement Resodont ("Latus”, Ukraine) - № 1; Endocort zinc oxide-eugenol cement ("Latus”, Ukraine) - No. 2; materials based on zinc oxide eugenol cement with dexamethasone: Endomethasone ivory (Septodont, France) - No. 3 and Endofil ("Produit Dentaires SA", Switzerland) - No. 4. To assess the antimicrobial activity of the studied materials, test microorganism strains were used: Staphylococcus aureus ATCC 25923, Enterococcus faecalis ATCC 6783, Candida albicans ATCC 885-653.

As a result of the study, it was established that filling materials have different antimicrobial activity. Resodont has the greatest antimicrobial activity on the test culture. Endomethason is active in relation to the test cultures studied, inferior to Resodont in its antimicrobial properties. Endocort and Endofil have less antimicrobial activity than Resodont and Endomethason, but have approximately equal growth retardation rates. It should be noted that with respect to Staphylococcus aureus, Endocort was found to be almost 1.5 times more active than Endofil.

The conducted studies confirm that the materials for filling of root canals by Resodont and Endocort (Latus, Ukraine) have a pronounced antibacterial effect. They are competitive with foreign sealers and are the materials of choice, having a significantly lower cost.
\end{abstract}

Key words: endodontic microbiology; root canal treatment; antimicrobial activity of sealers

\section{Introduction}

Despite accumulated experience knowledge and modern abilities in endodontic, the percentage of failed treatment of complicated caries in Ukraine is quite high, main causes of unsatisfactory endodontic treatment are disorders of standards of irrigation and filling of root canals. Often dentists do not consider the features of filling materials for obturation [1].

In endodontic practice there are number of root canal obturation techniques, each of them has its own advantages and disadvantages. Nowadays, most popular method among endodontists, is obturation of root canals with gutta-percha and sealer [2, 3].

According to many prominent researchers' perfect sealer should not irritate the periodontal tissues, densely obturate root canals both in lateral and vertical directions, not let the sealer shrink in root canals, it should also have antibacterial effect, be hydrophobic, biocompatible, nontoxic and radiopaque. it should not affect the tooth color and at the same time should be able to polymerasequickly, should have good adhesive feature to the dentine and gutta-percha[4,5].
For final obturation of root canals, different filling materials are used: based on zinc oxide eugenol (with different therapeuticadditives) and epoxy resin, and resorcinol-formaldehyde and etc.[6].

Zinc oxide-eugenol pastes represent cements modified for endodontic treatment $[7,8,9]$. Advantages of this sealers are connected to prolonged antimicrobial effect which is provided with releasing of eugenol. Using zinc-oxide-eugenol cements as sealers immediately after the filling of root canals provides the absence of microbial insertion in periodontium, which mostly depends on quality of obturation of root canals and not on the effect of antibacterial paste. Positive features of zinc oxide-eugenol cements are anti-inflammatory and pail relieving effects and the ability to use it in relatively dry root canal.

This material is pliable, easy to insert and extract from root canal, has satisfactory adhesive feature to canal walls and does not shrink. Despite advantages there are disadvantages too, for example it can destroy the polymerization of composites, has a strong cytotoxic effect on the culture of the fibroblast. Inhibits the function of macrophage $[10 ; 11]$. For enhancing the positive qualities of the materials in this group, the 
additional components are introduced: corticosteroids, thymol, paraformaldehyde, etc. Their cytotoxic and carcinogenic effects are proved.

Analysis of modern domestic and foreign literature shows that there is still no filling material for the root canals of the teeth, which would have the universal antimicrobial properties and could satisfy all the requirements of dentists in the treatment of complicated caries.

The studies of many authors have shown that composition of the root canals microflora depends on the nature of inflammatory process. Most often in the contents of the root canals are anaerobic microorganisms. The key element in the success of caries complications treatment is the choice of filling materials [11].

Currently, there is a large amount of zinc - oxide eugenol cement for the root canal obturation on the market, the cost of which depends on the manufacturer. There was set a task before us - to study the antimicrobial properties of some obturation materials, in order to improve the quality of treatment of complicated caries.

The purpose of the study: a comparison of the antimicrobial activity of in-vitro 4 materials for the root canal filling.

\section{Materials and methods}

The antimicrobial activity of filling materials was studied. Samples: Resorcin-formalin cement Resodont ("Latus", Ukraine) - № 1; Zinc oxide-eugenol cement Endocort ("Latus”, Ukraine) - № 2; Two materials based on the zinc oxide-eugenol cement with dexamethasone: Endomethasoneivory ("Septodont”, France) - № 3 and Endofil («ProduitDentairesSA», Switzerland) - №4.

According to the WHO recommendations, to evaluate the antimicrobial activity of the studied materials the microorganisms test-strains were used: StaphylococcusaureusATCC 25923, EnterococcusfaecalisATCC 6783, CandidaalbicansATCC 885-653 [12]. The microbial load was $10^{7}$ microbial cells per $1 \mathrm{ml}$ of environment and was established according to the mcfarland standard. There were used 18-24 hours of microorganism cultures, while the C. Albicans culture was preliminarily grown on Saburo environment with $2 \%$ glucose solution, and the cultures of S. Aureus and E. Faecalis - on Mueller-Hinton agar (HI media, India).

The antimicrobial activity of filling materials was determined by the method of "wells" (a method of diffusion into agar) with determination of diameters in the zones of growth retardation of microorganisms [13, 14]. This method is based on the ability of the active ingredient of the drug to diffuse into the agar on which the seeding of the test culture is performed. Determination of the antibacterial properties of materials was carried out on two layers of the dense nutrient environment poured into Petri dishes. In the lower layer, the non-seeded environment of Muller-Hinton was used: the melted nutrient environment was poured into Petri dishes in the amount of $10 \mathrm{ml}$; after agar hardening, the sterile stainless steel cylinders $10 \mathrm{~mm}$ high and $9 \mathrm{~mm}$ in diameter were applied to it. 4 cylinders were placed in one cup. In parallel, the melted nutrient environments were poured in $13.5 \mathrm{ml}$ into test tubes, where, after cooling the agar to $40-45^{\circ} \mathrm{C}$, $1.5 \mathrm{ml}$ of suspension of microorganisms was added. The top layer was thoroughly mixed and poured: it was poured around the cylinders obtained from $15 \mathrm{ml}$ of environment, seeded with the appropriate microorganism. After solidification of the top layer of agar with steriletweezers, the cylinders were removed and in the formed holes the study drug was put, prepared in accordance with the instructions of manufacturers.

The plates were kept for $30 \mathrm{~min}$ at room temperature and then the seedings were incubated in a thermostat at $37^{\circ} \mathrm{C}$ for $18-24 \mathrm{~h}$. Observations and calculations were carried out for 3 days at zones of growth retardation around "wells" (in $\mathrm{mm}$ ), including the diameter of the "well" itself. The medicinal substance of the drug diffuses into the agar, forming around the "well" a zone of inhibition of the growth of microorganism's sensitive to it, clearly standing out against the background of continuous growth. If the zones of oppression had an oval shape, then, in such cases, the largest and smallest diameters of the zone were measured and the average value was calculated, which was taken as an indicator.

Evaluation of antibacterial properties was carried out according to the following criteria:

Absence of the zones of growth retardation of microorganisms around the hole, as well as diameters of growth inhibition zones up to $10 \mathrm{~mm}$ indicate that the microorganisms are not sensitive to the sample introduced into the well, the drug was classified as inactive;

The zones of growth retardation of microorganisms with the diameter of $10-15 \mathrm{~mm}$ indicate a low sensitivity of the culture, a moderately active sample;

The zones of growth retardation of microorganisms with the diameter more than $15 \mathrm{~mm}$ are regarded as an indicator of sensitivity of the microorganism to the studied samples; the preparation was classified as an active agent.

For the reliability of the obtained results, the study was repeated three times. The data obtained during the study were subjected to statistical processing. The reliability of the identified differences of the studied parameters was evaluated using the Mann-Whitney test for independent samples [15].

The microbiological studies were conducted at the base of Department of Clinical Immunology and Microbiology of the Kharkov Medical Academy of Postgraduate Education of the Ministry of Health of Ukraine.

\section{The research results and their discussion}

The study showed that the filling materials have different antimicrobial activity, which depends on the type of microorganism and the chemical composition of the material (Table 1.).

Study of the antimicrobial activity of various materials for root canal filling in relation to reference microorganism strains

\begin{tabular}{|l|c|c|c|c|}
\hline \multirow{2}{*}{ Test-culture } & \multicolumn{3}{|c|}{ Zones of growth retardation of microorganisms around the hole with } \\
filling material, mm
\end{tabular}

Note: * - secondary culture growth; №1 - Resodont («Latus», Ukraine); №2 - Endocort («Latus», Ukraine); №3 - Endomethasone ivory («Septodont», France); №4 - Endofil («Produit Dentaires SA», Switzerland). 
The greatest bacteriostatic effect on Candidaalbicans was expressed in Resodont, where the zones of growth retardation of microorganisms was - 50,2 $\mathrm{mm}$ and Endomethasone - with the zone of growth retardation $40.0 \mathrm{~mm}$. While Endofil, the zone of growth retardation was within 22.0 $\mathrm{mm}$, and at Endocort $-20.0 \mathrm{~mm}$. These results show that all materials actively suppress the growth of Candidaalbicans.

But at the same time, we can state that after curing the material, we detected a secondary growth of the culture, which indicates activity of the material only until the moment of complete polymerization as a result of the direct activity of phenolic compounds released during curing (Fig. 1.)
The greatest bacteriostatic effect on Candidaalbicans was expressed in Resodont, where the zone of growth retardation was - 50,2 $\mathrm{mm}$ and Endomethasone - with a zone of growth retardation was $-40.0 \mathrm{~mm}$. While to Endofil, the zone of growth retardation was within $22,0 \mathrm{~mm}$, and to Endocort $-20.0 \mathrm{~mm}$. These results show that all the materials actively suppress the growth of Candidaalbicans.

But at the same time, we can state that after curing the material, we have detected the secondary growth of the culture, which indicates activity of the material only until the moment of complete polymerization as a result of the direct activity of phenolic compounds released during curing (Fig. 1.)
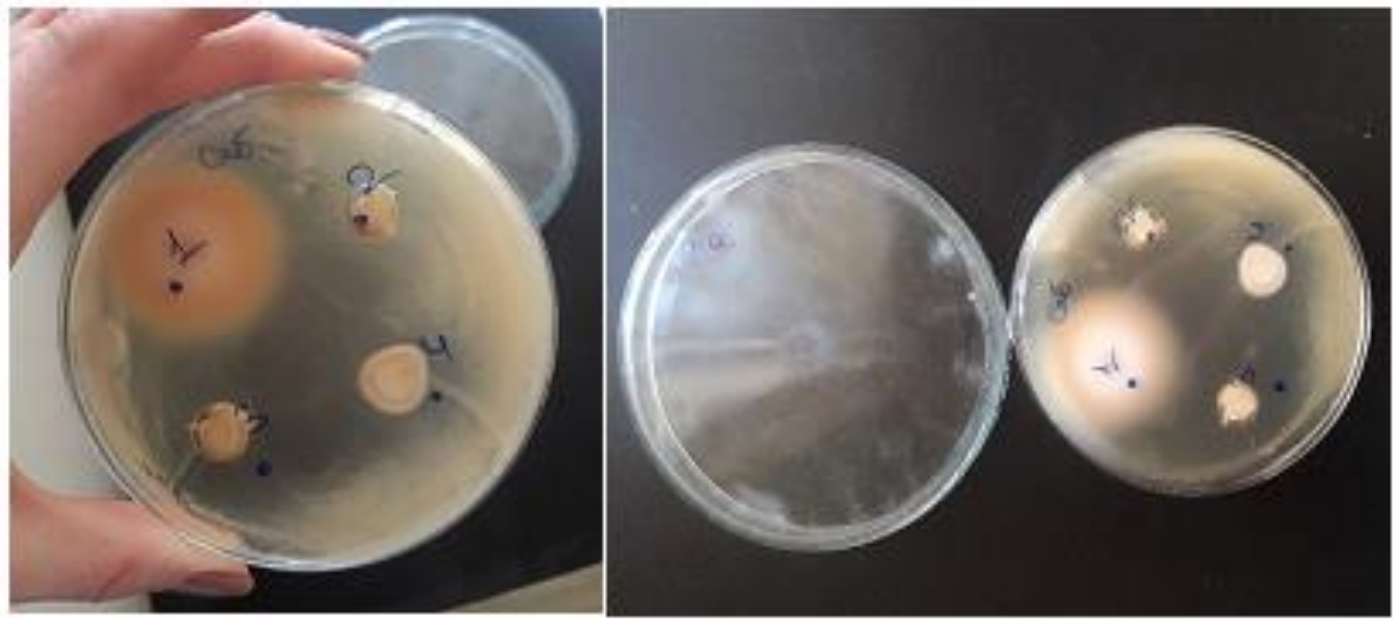

Figure 1: Accounting of growth inhibition zones C. albicansATCC 885-653 ( method of "wells").

Filling material : №1 - Resodont («Latus», Ukraine); №2 - Endocort («Latus», Ukraine); №3 - Endomethasone ivory («Septodont», France); №4 Endofil («Produit Dentaires SA», Switzerland).

The significant changes are observed in the study of growth retardation of St. aureus. Resodont and Endomethasone have expressed bacteriostatic activity $-50,4$ and $50,0 \mathrm{~mm}$ growth retardation zones, respectively. Endocort also actively suppresses the growth of this microorganism, which is $34.1 \mathrm{~mm}$. The growth retardation indicators in Endofil - is $22.1 \mathrm{~mm}$, which indicates its lowest activity to St. aureus compared to other materials. The results obtained characterize that all the materials as active agents' relative to St. Aureus (Figure 2). In addition, the given materials were also active after their polymerization, as evidenced by the data on the absence of secondary growth of a culture of staphylococcus.
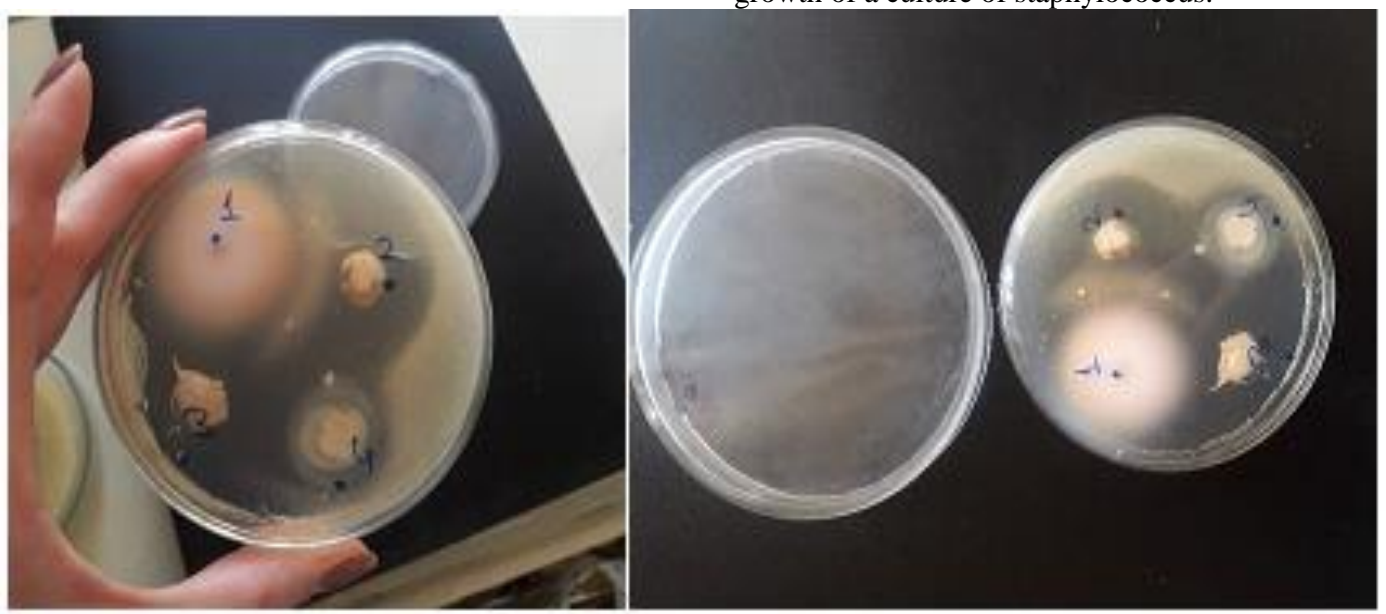

Figure 2: Accounting of growth inhibition zones S. aureusATCC 25923 (method of “wells”). Filling material: №1 - Resodont («Latus», Ukraine); №2 - Endocort («Latus», Ukraine); №3 - Endomethasone ivory («Septodont», France); №4 - Endofil («Produit Dentaires SA», Switzerland).

Growth of E. faecalis inhibits Resodont - the zone of growth retardation is $35.1 \mathrm{~mm}$ and Endomethasone - $25 \mathrm{~mm}$, but at the same time we observe appearance of the secondary growth around the holes with the indicated materials (Fig. 3). Endofil had a moderate activity to the reference strain of E. faecalis (with a growth retardation zone of $14.2 \mathrm{~mm}$ ) and the lowest activity in this study had Endocort - $12 \mathrm{~mm}$, but at the same time, Endofil and Endocort did not have the secondary growth of enterococcus culture. 


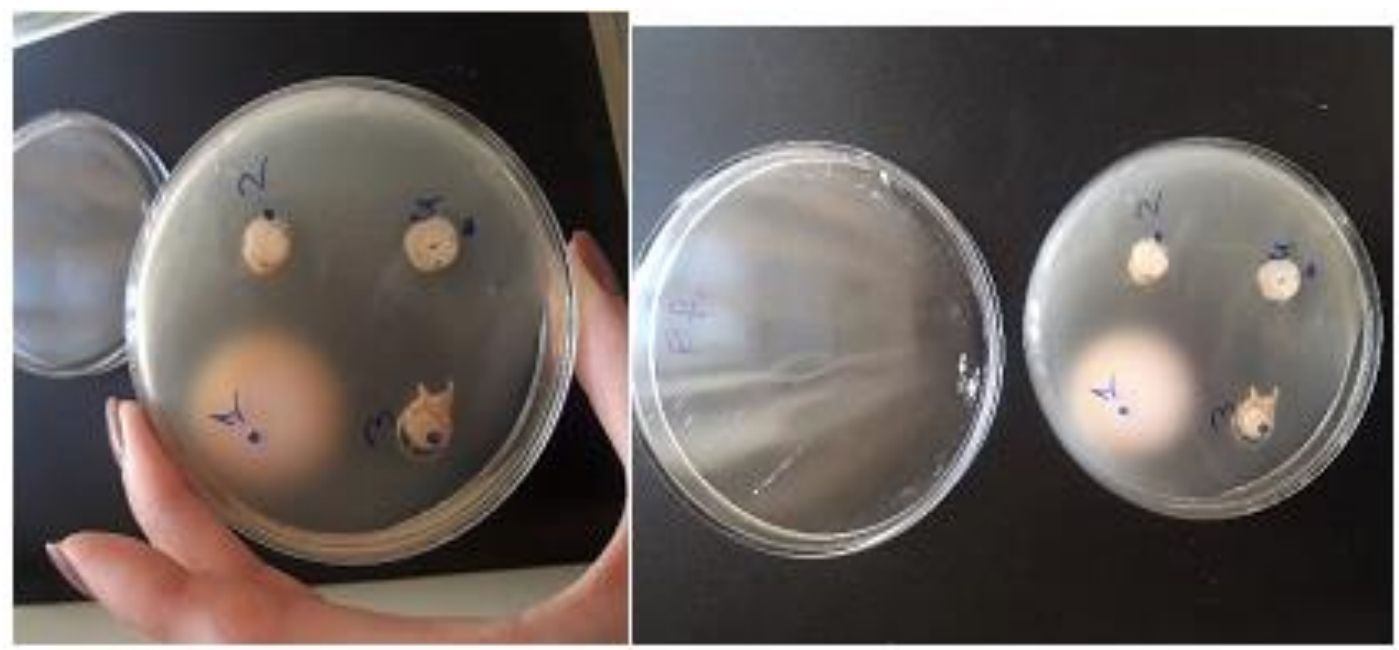

Figure 2: Accounting of growth inhibition zones E. faecalisATCC 6783 (method of “wells”). Filling material : №1 - Resodont («Latus», Ukraine); №2 - Endocort («Latus», Ukraine); №3 - Endomethasone ivory («Septodont», France); №4 - Endofil («Produit Dentaires SA», Switzerland).

In this way, the filling materials have different antimicrobial activity. Resodont has the greatest antimicrobial activity on the test-culture. Endomethasone is active in relation to the examined test-cultures, inferior to Resodont in its antimicrobial properties. Endocort and Endofil have less antimicrobial activity than Resodont and Endomethasone, but have approximately equal growth retardation rates. It should be noted that relative to Staphylococcus aureus Endocort was almost 1.5 times more active than Endofil.

The conducted studies confirm that the materials for filling root canals Resodont and Endocort ("Latus", Ukraine) have an expressed antibacterial effect. They are competitive with the foreign sealers and are the materials of choice, having a significantly lower cost. The materials of the company "Latus" (Ukraine) are available in ergonomic and aesthetic packaging. All this allows us to recommend Resodont and Endocort for use for endodontic treatment.

\section{References}

1. Kononova OV. (2017) Current State of Endodontic Treatment of Pulpit in the Population of Ukraine Visnyk Vdnzu "Ukrainian Medical Dental Academy". 15(3) (51), part 1,296-230.

2. Македонова Ю.А. Comparative characteristics of the effectiveness of materials in filling root canals with intact periodontium: author's ref. diss. Cand. med.nauk / Yu.A. Македонова. - Volgograd, 2012. - 23 p.5.

3. Comparative characteristics of modern sealers and preferences of dentists / A.S. Косилова, Д.А. Oskolkova, T.O. Pleshakova [et al.] // Problems of dentistry. - 2012. - №5. - P.26-30.

4. Modern endo-sealants for endodontic treatment of teeth: a method. recommendations / G.G. Чистякова. - Минск: БГМУ, 2007. - $20 \mathrm{c}$.

5. Morphological Analysis of the Condition of the Periodont When Using Different Types of Silers in Endodontics IV Firsova, Yu.A. Македонова, В.Ф. Михальченко, Д.В. Михальченко, С.В. Поройский, A.B. Arutyunov // MEDICAL BULLETIN OF THE NORTH CAUCASUS- 2015. T. 10. № 4- P.389 -394.
6. Ryabokon EN, Dnestransky VI Experimental Evaluation Of The Quality Of Sealing Of Root Channels At Different Types Of Their Treatment \I Actual problems of modern medicine - Volume 16, Issue 1 (53) -P.39-47.

7. Lyubchenko OV Root sealants. The problem of choice. Literature review / OV Lyubchenko // News of dentistry. - 2011. - № 3. - P. 6-11.

8. А.В. Ларинская, А.В. Юркевич, И.Д. Ушницкий, Т.Е. Kruglov Comparative Characteristics Of Modern Endogermetics II Yakutsky Medical Journal- 1 '2018-P.75-77

9. Bruna Feltrin Antoniazzi. Carine Weber Pires. Carmela Rampazzo Bresolin. Rita Niederauer Weiss. Juliana Rodrigues Praetzel (2015) Antimicrobial activity of different filling pastes for deciduous tooth treatment. Braz Oral Res [online]. vol.29 (1), pp. 1-6.

10. Marymova EB, Adamovich EI, Makedonova Yu.A., Poroyskaya AV, Pavlova-Adamovich AG Morphological Evaluation Of Periodontal Changes In Contact With Endogermetics // Modern problems of science and education. - 2015. - -1 1-1.

11. Morphological Analysis Of The Condition Of The Periodont When Using Different Types Of Silers In Endodontics IV Firsova, Yu.А. Македонова, В.Ф. Михальченко, Д.В. Михальченко, C.В. Поройский, A.B. Arutyunov // MEDICAL BULLETIN OF THE NORTH CAUCASUS- 2015. T. 10. № 4- P.389 -394.

12. (1994) Basic laboratory techniques in clinical bacteriology. Ed. WHO. - Geneva, pp.31.

13. State Pharmacopoeia of Ukraine / State Enterprise "Ukrainian Scientific Pharmacopoeial Center for Quality of Medicines". - 2nd type. - Appendix 2. - Kharkiv: State Enterprise "Ukrainian Scientific Pharmacopoeial Center for Quality of Medicines", 2018. - 336 p. ISBN 978-966- 97390-3-2

14. Methodical recommendations for studying the specific activity of antimicrobial drugs. (2004) Compilers / Yu.L. Volyansky, IS Гриценко, В.П. Shirobokov and others. - К. 21-22.

15. Mincer OP. (1982) Methods of processing medical information / OP Minzer, BN Ugarov, VV Vlasov. - К .: Вища школа. 158. 
(c) ()

This work is licensed under Creative

Commons Attribution 4.0 License

To Submit Your Article Click Here: Submit Manuscript

DOI: $10.31579 / 2690-4861 / 116$
Ready to submit your research? Choose Auctores and benefit from:

* fast, convenient online submission

* rigorous peer review by experienced research in your field

* rapid publication on acceptance

* authors retain copyrights

* unique DOI for all articles

* immediate, unrestricted online access

At Auctores, research is always in progress.

Learn more www.auctoresonline.org/journals/international-journal-ofclinical-case-reports-and-reviews 